\title{
Mathematical Critical Thinking and Curiosity Attitude in Problem Based Learning and Cognitive Conflict Strategy: A Study in Number Theory course
}

\author{
Zetriuslita $^{1,2}$, Wahyudin ${ }^{2} \&$ Jarnawi $^{2}$ \\ ${ }^{1}$ Universitas Islam Riau, Pekanbaru. Riau, Indonesia \\ ${ }^{2}$ Universitas Pendidikan Indonesia, Bandung, Indonesia \\ Corresspondence: Zetriuslita, Pendidikan Matematika FKIP Universitas Islam Riau Pekanbaru Riau, Indonesia. \\ E-mail: zetriuslita@edu.uir.ac.id
}

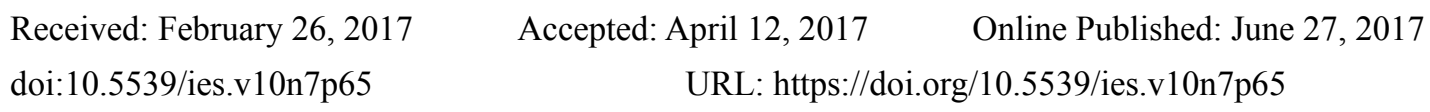

\begin{abstract}
This research aims to describe and analyze result of applying Problem-Based Learning and Cognitive Conflict Strategy (PBLCCS) in increasing students' Mathematical Critical Thinking (MCT) ability and Mathematical Curiosity Attitude (MCA). Adopting a quasi-experimental method with pretest-posttest control group design and using mixed method with sequential explanatory strategy, the study involves undergraduate students of Mathematics Education Program at a private university in Riau, Indonesia, academic year 2015/2016 enrolled in Number Theory course. Quantitative data were obtained from essay test and questionnaire whereas qualitative data were from interview and observation. The findings show that; (1) there is a difference between MCT ability taught by PBLCCS and Explicit Direct Instruction (EDI), (2) there is no significant difference between MCA taught by PBLCCS and EDI, (3) students still face obstacles in developing their critical thinking skills when solving matematical problems.
\end{abstract}

Keywords: mathematical critical thinking, mathematical curiosity, problem-based learning, cognitive conflict strategy

\section{Introduction}

In this information era, critical thinking is a necessary skill that people should have to become good global citizens. With this skill, they will always be careful in making every decision on certain given problems. This skill is considered one of the chief goals and ideals in the area of education (Siegel, 2003, p. 141), including math education. As a fundamentally necessary skill, critical thinking has a complex concept including cognitive skills and affective dispositions that influence the way teachers in presenting educational concepts to students (Chukyuwenum, 2013, p. 18). This idea is reinforced by Facione et al. (1995) in Aktaş and Unlu (2013, p. 832) who argue that the disposition of critical thinking can help predict the critical thinking skills. Besides, critical thinking also supports intellectual curiosity (Thompson, 2011).

The higher the education level, the more required the critical thinking. This skill is considered more necessary at Higher Education, particularly for students of mathematics education department, in which each course requires them to critically solve certain given problems, following scientific reasoning, including in Number Theory course. At this level, critical thinking skill is believed to positively relate to academic achievement (Lee Wootton Chang, and Phan) as cited in Kondacki\& Aydin, 2013). Based on their study, students need to think critically when they face certain challenges as they have to consider and carefully evaluate information received before they can take a decisive action. With this capability, students can choose what they think as important and then make plans and careful decision to solve their problems. Within this process, they can compare available information, find their similarities and differences, and crosscheck certain contradictory evidences to see whether they have any consistency or irregularity. In fact, critical thinking skill enables people to be sensitive to any information received so that they can react positively and provide solutions to any problems they are facing.

Furthermore, critical thinking skill has strong relation to curiosity. This attitude serves as an initial step of the skill. Curiosity is a phenomenon usually characterized by an effort made to search and find something which leads to enthusiasm to learn, find out and investigate (Suhadak \& Wutsqa, 2014). Supporting this 
definition, Mc ELmeel (2002) argues that curiosity can be identified from a desire to learn, investigate, and find out. As a part of motivation, curiosity is also important to be developed in learning (Shellnut (1996) as cited in Suhandak \& Wushqa, 2014, p. 61). One important role that curiosity plays is that it can encourage and build learners' knowledge. Considering its significant role in learning, the development of curiosity in learners should become the main focus of learning. It is argued that the more learners feel curious about something they learn, the closer they are with their learning environment, including their work groups (Binson, 2009).

As a response to this demand and to develop students' critical thinking ability and mathematical curiosity, teachers and other educators need to develop a learning model which focuses on learning autonomy, by giving students a more dominant role to develop themselves during the learning process in which teachers serve only as facilitators. One learning model which is believed to adopt this learning autonomy is Problem-Based Learning (PBL) and Cognitive Conflict Strategy (CCS). Therefore, this study proposes the following hypothesis:

1) There is a different development of critical-mathematical thinking skill between learners who are taught by using Problem Based Learning Cognitive Conflict Strategy (PBLCCS) and those taught by Explicit Direct Instruction (EDI).

2) There is a different attitude development of mathematical curiosity between those who are taught by using Problem Based Learning Cognitive Conflict Strategy (PBLCCS) and learners taught by Explicit Direct Instruction (EDI).

\section{Literature Review}

\subsection{Problem Based Learning}

As a learning model, Problem Based learning (PBL) has a relatively long history. It was initially used in medical education, at the faculty of medicine, McMaster University in Canada in the mid 1960's. Soon after, three other medical schools, the University of Limburg at Maastricht in the Nedherlands, the University of Newcastle in Australia, and the University of New Mexico in the United States, adapted the McMaster model of PBL into their more specific subject areas before developing a model of their own (Camp, 1996, p.1). As a result of this various adaptation, PBL is believed to have become a solid learning model which can sufficiently support the development of learners' critical thinking skills in a diverse subject areas (Kek \& Huijser, 2011, p. 331), including mathematics education. In addition, Camp (1996, p. 3) also claims that this model is also supported by constructivist learning views which is applicable in all educational institutions from kindergarten to tertiary levels, including the area of medical education and training.

Since its early conception in medical education, PBL has been growing significantly that it was later begun to be adapted and used in other areas of education, particularly mathematics education. Appling this model in their research, for instance, Okinoğlu and Tandoğan (2006) found that PBL has positive results on students' learning results as well as their understanding about concept and learning attitudes. Using a slightly different model, activity-based learning, MacSath, Wallace and Chi (2009) applied a similar study with the following criteria: a) using small group collaboration to solve the problem given, b) giving more autonomy for students to be the learning center, c) using real life problem, and d) assigning teacher as facilitator. The findings show that this model of activity-based learning can significantly improve learners' attitudes, understanding of concepts and learning results.

Theoretically, PBL is based on Piaget's constructivist and Vygotsky's social constructivist learning theories (Orey, 2010). Piaget's theory is based on the belief that learning should be based on the cognitive development of children with schemata as its basic structure. Meanwhile, Vygotsky emphasizes the importance of social environment in children's construct development. Vygotsky's theory centers on two main concepts: zone of proximal development (ZPD) and scaffolding. ZPD is understood as a distance between children's level of actual development which is defined as autonomous critical thinking ability and that of their potential development which is defined as critical thinking ability under adult guidance through collaboration with peers of higher ability (Herman, 2006).

\subsection{Cognitive Conflict Strategy}

In addition to PBL, Cognitive Conflict Strategy (CCS) is also believed to able to stimulate learners' critical thinking. Cognitive Strategy is defined as a mental procedure used to achieve different cognitive purposes ranging from the lowest and most natural like sensing to the more cognitive ones such as observing, saving, recalling, imagining and thinking (Surya, 2015). Bruner (1971) and Gagne (1985) as cited in Surya (2015) define cognitive strategy as a procedure used to find out and solve problem. Meanwhile, Cognitive Conflict means 
different perceptions (opinions) which lead to conflict between two groups. A conflict happens when an individual experiences uncertainty in deciding to choose one or more among many choices.

Furthermore, cognitive strategy and cognitive conflict are combined into cognitive conflict strategy. Based on Piaget's constructivist learning, this strategy states that when learners construct their knowledge, they need to assimilate what they have learned with the new concept they are learning so that they can reach a more balanced higher knowledge (Woolfolk, 1984). In relation to this, Piaget claims that learners actively reorganize knowledge that they have acquired in their cognitive structure. With time and experience, their cognitive structure develops and adapts new knowledge through assimilation and accommodation.

Assimilation and accommodation are interrelated. Santrock (2012) states that assimilation is a process in which information coming into brain is changed in ways, that it matches the structure of the brain. Meanwhile, he also argues that accommodation is the process of brain structure change as the result of observation and information. Giving further accounts of both assimilation and accommodation, Santrock describes two phases that learners need in their learning to achieve some desired changes. The first phase is assimilation and the second one is accommodation. The process of assimilation enables learners to make use of concepts that they have learned to adjust to the new one. Meanwhile, in accommodation, learners change some concepts in their brains which they believe incompatible with some new phenomena which they are facing.

Cognitive conflict needs incentive. In learning process, this stimulation has a significant role in helping the process of assimilation so that it becomes more effective and meaningful in learners' intellectual struggle. Commenting on this, Jarnawi (2012) argues that cognitive conflict occurs less frequently in collaborative than personal contexts. Collaboration is the right time for learners to personally reconcile conflicts that appears in themselves. The stimulation of cognitive conflict that learners experience during the learning process will make the assimilation process in their intellectual journey to become more effective and meaningful.

Furthermore, providing a more detail account, Ismaimuza (2010) argues that cognitive conflict strategy has a common pattern which include exposing alternative framework (revealing initial concept), creating conceptual cognitive (creating conceptual conflict), and encouraging cognitive accommodation (requesting cognitive accommodation).

The following example show a cognitive conflict situation in integral calculus of sub-calculus material

Problem: Find out if the area bounded by equation of curve $y=x^{3}$ and restricted by $x=-1$ dan $x=1$ is zero?

Answer: Using the integral procedure, it is obtained that:

$$
\left.\int_{-1}^{1} x^{3} d x=\frac{1}{4} x^{4}\right]_{-1}^{1}=\frac{1}{4}(1-1)=0
$$

The next question:

Based on the answer, are you sure with the obtained result? Check again more carefully, is there anything wrong or has the question provided complete information? What should you do next? Do you need to make a graph functions? Check and do it again.

The above example is one of the integral calculus questions which includes cognitive conflict. This question is used to evoke students' confusion so that they are willing to find out more using their critical thinking skills. Students may have problem in answering this question because it is imposibble to find zero as an integral area. To solve this question, students need to draw the chart of function and the area bounded is given.

\subsection{Problem Based Learning (PBL) and Conflict Cognitive Strategy (CCS)}

In addition to PBL, cognitive conflict strategy (CCS) can also reinforce the critical thinking skills of learners. Based on the steps PBL and CCS, then a combination of both steps is compiled and named the Problem Based Learning Cognitive Conflict Strategy (PBLCCS), which has 5 steps as follows:

1) Orientation of the problem (conflict identification)

a) Giving students a problem which has conceptual challenge (a cognitive conflict) which leads to disequilibrium among students.

b) Directing students to relate the newly received information to the background knowledge they have obtained (assimilation). 
c) Identifying if students agree or disagree with the new information given (accommodation).

2) Learning group organization

3) Individual and in-group supervision

a) Students understand the given problem on their own.

b) Lecturer facilitates students in solving the given problem.

c) High achieving students help their low achieving peers complete the assigned conflict.

4) Work development and presentation

a) A few group representatives present the result of their group works.

b) Non-presenting groups are given opportunity to ask and comment on the presentation.

5) Analysis and evaluation of the process of solving a given problem or conflict

\subsection{Mathematical Critical Thinking (MCT)}

Critical thinking is the basis of Mathematical Critical Thinking (MCT) ability. Johnson (2007) defines critical thinking as a clear and focus process of mental activities which include problem solving, decision making, persuasive activities, assumption analysis, and scientific research. In a similar tone, Santrock (1997) states that critical thinking is an activity which involves deeper meaning of problems, keeping an open mind about different approaches and perspectives, not accepting on what other people and books tell, and thinking reflectively rather than accepting the first idea coming to mind" (p. 78). Additionally, critical thinking is also defined as analytical and reflective thinking that includes activities of testing, questioning, correlating and evaluating all aspects of a given situation or problem (Krulik \& Rudnick, 1995). Meanwhile, Yeats (2005) defines critical thinking as a process of assessment and analysis in order to improve the thinking process itself. In line with Krulik and Rudnick (1995), Dewey (1909) as cited in Fisher (2001) says that critical thinking is a reflective process. This idea is also reinforced by Ennis $(2011$, p. 1) who argues that critical thinking is focused and reflective reasoning activities in deciding what people believe and how they behave based on their beliefs.

Furthermore, critical thinking is both theoretical knowledge and applicable skill. Glaser as cited in Fisher (2008) defines critical thinking as: (1) an attitude or willingness to think deeply and seriously about issues and aspects that are within the reach of one's experience; (2) knowledge about the methods of inspection and logical reasoning; (3) some kind of skills to apply these methods. In other words, critical thinking requires effort to examine any beliefs or assumptive knowledge based on relevant supporting evidences, and further derived conclusions. To complete this, Ennis (1993) as cited in Duron, et al. (2006) argues that critical thinking is the ability to perform high-level of Bloom's taxonomy such as doing analysis, making synthesis and evaluation.

Based on the above mentioned various definitions and characteristics, it can be concluded that critical thinking is a clear, focused and in-depth mental activity which includes problem identification, decision making, assumption analysis, and reflection on certain issues.

\subsection{Mathematical Curiosity Attitude (MCA)}

In addition to Problem-Based Learning and Cognitive Conflict Strategy (PBLCCS), this study also discusses Mathematical Curiosity Attitude (MCA) as an important aspect in learning success. According to Binson (2009), curiosity is a tendency to inquire, investigate and find out more after having knowledge about something. It is also the tendency to inquire, investigate, and seek a framework to think about curiosity about something more deeply. This high desire for knowing something or looking for answers to certain questions is the catalyst for developing someone's science abilities, including students of mathematics education. Litmann and Spielberger (2003) as cited in Reio et.al (2006) states that curiosity is the desire to acquire new information and knowledge, as well as a new sensory experience that can motivate behavior to find out more. Also Carin (1987) as cited Ismawati, et.al (2014) defines curiosity is as wants and needs someone to obtain an answer to a question or things that cause a deep curiosity.

In addition, Santoso (2011) also argues that curiosity or a desire to know something is the basic nature of humans who keep asking whatever they see and find before asking why or how something happens. These questions then continue and develop into more advance ones by asking why a problem occurs, how something happens and how to find solution to this problem. Such these critical questions are typical to human beings and can be identified from the very beginning they can talk and express their feelings to other humans. 


\section{Method}

\subsection{Research Design}

This research uses a quasi-experimental design (Creswell, 2010, Cohen et al., 2007), aiming to obtain quantitative data on the ability of students' Mathematical Critical Thinking (MCT) and Mathematical Curiosity Attitude (MCA). Students in experiment group were exposed to Problem Based Learning and Cognitive Conflict Strategy (PBLCCS) whereas those in control group are taught by Explicit Direct Instruction (EDI). The research design also combines both quantitative and qualitative methods with sequential explanatory strategy (Creswell, 2010). Quantitative data were collected from questionnaire administered prior to qualitative data (interviews). Each of quantitative and qualitative data was first analyzed separately since they have different characteristics. In this mixed method, quantitative part serves as the primer data source whereas qualitative become secondary. The results of two methods were finally combined to answer the research questions.

Within quantitative phase, statistical analysis was used to find out question on quantitative measurement. Meanwhile, the qualitative stage focused on the analysis of students' works followed by interviews to investigate further information on students' mathematical critical thinking process in completing the assigned problems or tasks.

The design used in this study is pre-test and post-test non-equivalent group, which Cohen et al. (2007) describe as follows:

Table 1. Pre-test and Post-test Non-equivalent group design

\begin{tabular}{lccc}
\hline & Pre-test & Treatment & Post-test \\
\hline Experiment & $\mathrm{O}_{1}$ & $\mathrm{X}$ & $\mathrm{O}_{2}$ \\
Control & $\mathrm{O}_{3}$ & - & $\mathrm{O}_{4}$ \\
\hline
\end{tabular}

Note. $\mathrm{O}_{\mathrm{i}}$ : The result of pre-test and post-test from experimental and control groups; X: Treatment of PBL (Problem-based learning) with Cognitive Conflict Strategy (PBMCCS); -: Treatment with Explicit Direct Instruction (EDI).

\subsection{Participants}

The population in this research is all students of third semester (five classes, 3A-3E) in mathematics education of a private university in Riau province of Indonesia. Since students in these classes have relatively similar capability as they are randomly placed, a cluster random sampling was used to identify 51 students of class $3 \mathrm{~B}$ and class $3 \mathrm{C}$ in the academic year of 2016/2017 as samples. Twenty-five students from class 3B were selected as experiment group and taught by PBLCCS learning model whereas another 26 student of class $3 \mathrm{C}$ as control group were exposed to EDI learning model.

Furthermore, to provide all participating students in both groups with similar instruction, facilities, time and learning materials, the teaching in both experiment and control groups was conducted by the same instructor on the same day within two relatively close teaching sessions so that students' learning conditions can be properly controlled.

\subsection{Data Collection}

\subsubsection{Instruments}

The study has both quantitative and qualitative instruments. The first includes essay test about citical thinking skill and questionaire on learner's curiosity attitude and the second is interview. The essay test is developed from O'Daffer and Thornquist (1993) and Gokhale (1995) as cited in Hidayat (2010), as well as that of Ennis as cited in Innabi (2003), and Costa (1985). The essay test has the following indicators of critical thinking skill:

1) Identification skill, that is the ability to give a reason to the mastery of the concept;

2) Connection skill, namely the ability to find and connect facts, data, and concepts.

3) Analysis skill, that is the ability to select and analyze uncertain and necessary information from the given problem

4) Evaluation skill, namely the ability to find and detect things that are important from the concept given

5) Problem solving skill, the ability to understand the problem, choose a strategy and implement the solution of the given problem. 
Meanwhile, the questionaire is developed from Suhandak (2014), McElmeel (2002), Binson (2009), which has some indicators as follow:

1) Inquiry about information or a given problem

2) Desire and want to find out details

3) Enthusiasm/motivation in learning

4) Search for information from various sources

5) Trial of alternative problem solving

\subsubsection{Data Analysis}

Quantitative data were analyzed using statistical descriptions, t-test, Mann-Whitney U-test (normal distribution of data), one-way ANOVA, Kruskal-Wallis-test (when data are not normally distributed). To determine the increase of students' critical thinking ability and curiosity attitude, the following mathematical formula of normal-gain was used:

$$
N_{-} \text {Gain }=\frac{\text { posttest score }- \text { pretest score }}{\text { score } \text { maksimum ideal }- \text { pretest score }}
$$

(Meltzer, 2002)

High: $\quad N_{-}$Gain $>0.7$

Medium: $0.3 \leq N_{-}$Gain $\leq 0.7$

Low: $\quad N_{-}$Gain $<0.3$

Next, the Mann-Whitney U-test was used to analyze data from questionnaire on mathematical curiosity which have ordinal distribution. Finally, both quantitative and qualitative data were collected within three phases of the study; initial, middle and end. Data of test and questionnaire were first collected, followed by data of interviews. These two types of data were then combined to answer the research questions.

\section{Findings}

\subsection{Enhancement of Mathematical Critical Thinking (MCT) Skill}

Based on the statistical data, the increase in students' mathematical critical thinking skill can be described in the following Table 2:

Table 2. Gmean and standar deviation of MCT

\begin{tabular}{cccccc}
\hline \multicolumn{5}{c}{ Group Statistics } \\
\hline & Class & N & N_Gain Mean & Std. Deviation & N_Gain Category \\
\hline \multirow{2}{*}{ MCT } & EC & 25 & 0.87 & 0.20 & High \\
& CC & 26 & 0.55 & 0.22 & Medium \\
\hline
\end{tabular}

Note. EC: Experiment Class; CC: Control Class; N_Gain mean: Increase of Mean

Table 2 shows a different gain-average (N-Gain Mean) of students' critical thinking skills between the experiment class (EC) and the control class (CC). We can see that N_Gain in EC is greater than N_Gain in CC and a similar difference is also found in N_Gain category. Furthermore, to find out the result of statistical test, the study uses SPSS 20.00 software to identify the significance of homogenity of variances and differences in mean improvement of critical thinking ability (MCT). The result of homogenity of variances and enhancement of MCT can bee seen at Table 3 as follow:

Table 3. Test results of homogenity of variances and enhancement of MCT

\begin{tabular}{cccccc}
\hline Levene-test & Sig & Criteria & t-test & Sig (2-tailed) & Criteria \\
\hline 5.30 & 0.03 & Rejected $\mathrm{H}_{0}$ & 12.15 & 0.00 & Rejected $\mathrm{H}_{0}$ \\
\hline
\end{tabular}

As Table 3 above shows, Lavene-test yields sig $=0.03 \leq \alpha$, with $\alpha=0.05$. The testing criteria reject $\mathrm{H}_{0}$, which means that both classes are not homogeneous. So, $t$-test for equal variances not assumses was used to obtain Sig 
(2-tailed $)=0.00 \leq \alpha$, rejected $\mathrm{H}_{0}$, meaning that there is a different increase in mathematical critical thinking skills between experiment and control classes. Based on this finding, it is concluded that, compared to EDI, PBLCCS can yield a better mathematical critical thinking skill.

Furthermore, each indicator of critical thinking skill is analyzed as can be seen from Table 4 below:

Table 4. Average skill of mathematical critical thinking for each indicator

\begin{tabular}{|c|c|c|c|c|c|c|c|c|}
\hline \multirow{4}{*}{ Indicators } & \multirow{4}{*}{ QN } & \multirow{4}{*}{ Score } & \multicolumn{6}{|c|}{ Learning Model } \\
\hline & & & \multicolumn{3}{|c|}{ PBMCCS } & \multicolumn{3}{|c|}{ EDI } \\
\hline & & & \multicolumn{2}{|c|}{ Average } & \multirow{2}{*}{$N_{-}$Gain } & \multicolumn{2}{|c|}{ Average } & \multirow{2}{*}{ N_Gain } \\
\hline & & & Pretest & Posttest & & Pretest & Posttest & \\
\hline $\begin{array}{l}\text { Identification skill, that is the } \\
\text { ability to give a reason to the } \\
\text { mastery of the concept }\end{array}$ & $1 \mathrm{a}$ & 3 & 0.40 & 2.02 & 0.62 & 0.07 & 2.16 & 0.71 \\
\hline $\begin{array}{l}\text { Connection skill, namely the } \\
\text { ability to find and connect facts, } \\
\text { data, and concepts }\end{array}$ & $2 \mathrm{a}$ & 3 & 0.12 & 1.80 & 0.58 & 0.04 & 1.58 & 0.52 \\
\hline $\begin{array}{l}\text { Evaluation skill, namely the ability } \\
\text { to find and detect things that are } \\
\text { important from the concept given }\end{array}$ & $3 a$ & 3 & 0.08 & 1.84 & 0.60 & 0.00 & 1.62 & 0.54 \\
\hline $\begin{array}{l}\text { Evaluation skill, namely the ability } \\
\text { to find and detect things that are } \\
\text { important from the concept given }\end{array}$ & $4 b$ & 3 & 0.56 & 2.76 & 0.90 & 0.81 & 2.41 & 0.73 \\
\hline $\begin{array}{l}\text { Problem solving skill, the ability } \\
\text { to understand the problem, choose } \\
\text { a strategy and implement the } \\
\text { solution of the given problem }\end{array}$ & $5 a$ & 3 & 0.80 & 2.02 & 0.56 & 0.50 & 1.76 & 0.50 \\
\hline SMI & & 15 & 1.96 & 10.45 & 0.88 & 1.42 & 10.07 & 0.64 \\
\hline Category & & \multicolumn{4}{|c|}{ High } & & Middle & \\
\hline
\end{tabular}

Note. QN: Question Number; SMI: Score Maximum Ideal.

Based on Table 4, it is concluded that, in general, PBLCCS has been able to improve students' Mathematical Critical Thinking (MCT) skill than EDI as shown by a better N_Gain and N_Gain category for each indicator.

\subsection{Enhancement of Mathematical Curiosity Attitude (MCA)}

Based on data analysis using Mann-Whitney-U, the gain mean of Mathematical Curiosity Attitude (MCA) is described in Table 5.

Table 5. N_Gain Mean and standar deviation of MCA

\begin{tabular}{|c|c|c|c|c|c|}
\hline \multicolumn{6}{|c|}{ Group Statistics } \\
\hline & Class & $\mathrm{N}$ & N_Gain Mean & Std. Deviation & N_Gain Category \\
\hline \multirow{2}{*}{ MCA } & $\mathrm{EC}$ & 25 & 0.09 & 0.24 & Low \\
\hline & $\mathrm{CC}$ & 26 & 0.03 & 0.29 & Low \\
\hline
\end{tabular}

Note. EC: Experiment Class; CC: Control Class; N_Gain mean: Mean of Increase.

Table 5 shows that both experimental and control classes have different gain-average (N-Gain Mean) of Mathematical Curiosity Attitude (MCA). Furthermore, a statistical test was used to find out the significance of this variance difference by using software SPSS version 20.00. The results can be seen in Table 6 below.

Table 6. Test results of homogenity of variances and enhancement of MCA

\begin{tabular}{cccccc}
\hline Levene-test & sig & Criteria & t-test & sig (2-tailed) & Criteria \\
\hline 0.06 & 0.81 & accepted $\mathrm{H}_{0}$ & 0.85 & 0.40 & accepted $\mathrm{H}_{0}$ \\
\hline
\end{tabular}


As Table 6 shows, Lavene-test yields sig $=0.81 \geq \alpha$, with $\alpha=0.05$. The testing criterion accepts $\mathrm{H}_{0}$, which means that both classes have homogeneous variance. So, $\mathrm{t}$-test was used to find out equal variance assumption and obtained Sig (2-tailed) $=0.40 \geq \alpha$, accepted $\mathrm{H}_{0}$, meaning that there is no different increase in mathematical curiosity between experiment and control classes.

Furthermore, each indicator of critical thinking skill is analyzed as can be seen from Table 7 below:

Table 7. Average ability of mathematical curiosity for each indicator

\begin{tabular}{|c|c|c|c|c|c|c|c|c|c|}
\hline \multirow{4}{*}{ Indicators } & \multirow{2}{*}{\multicolumn{2}{|c|}{ Statement Number }} & \multirow{4}{*}{ SMI } & \multicolumn{6}{|c|}{ Learning Model } \\
\hline & & & & & $\mathrm{EC}$ & & & $\mathrm{CC}$ & \\
\hline & \multirow{2}{*}{$(+)$} & \multirow{2}{*}{$(-)$} & & \multicolumn{2}{|c|}{ Average } & \multirow{2}{*}{$N_{-}$Gain } & \multicolumn{2}{|c|}{ Average } & \multirow{2}{*}{$N_{-}$Gain } \\
\hline & & & & Pretest & Posttest & & Pretest & Posttest & \\
\hline $\begin{array}{l}\text { Inquiry about } \\
\text { information or a } \\
\text { given problem }\end{array}$ & $\begin{array}{c}1,5,10,12 \\
27,38\end{array}$ & $\begin{array}{c}16,17,29 \\
31\end{array}$ & 1000 & 0.77 & 0.78 & 0.04 & 0.70 & 0.71 & 0,03 \\
\hline $\begin{array}{c}\text { Desire and want } \\
\text { to find out } \\
\text { details }\end{array}$ & $4,9,11,25$ & $\begin{array}{c}13,23,24 \\
32\end{array}$ & 800 & 0.78 & 0.79 & 0.09 & 0.79 & 0.75 & $-0,19$ \\
\hline $\begin{array}{c}\text { Enthusiasm/moti } \\
\text { vation in } \\
\text { learning }\end{array}$ & $\begin{array}{c}3,6,8,15 \\
35\end{array}$ & $\begin{array}{c}18,20,22 \\
28,30\end{array}$ & 1000 & 0.71 & 0.72 & 0.03 & 0.69 & 0.70 & 0,03 \\
\hline $\begin{array}{c}\text { Search for } \\
\text { information } \\
\text { from various } \\
\text { sources } \\
\end{array}$ & $\begin{array}{c}2,26,33 \\
36\end{array}$ & 19,21 & 600 & 0.75 & 0.74 & -0.04 & 0.75 & 0.74 & -0.04 \\
\hline $\begin{array}{c}\text { Trial of } \\
\text { alternative } \\
\text { problem solving }\end{array}$ & $\begin{array}{c}7,14,34 \\
37\end{array}$ & 39,40 & 600 & 0.69 & 0.72 & 0.10 & 0.68 & 0.70 & 0,01 \\
\hline Total & \multicolumn{2}{|c|}{40} & 4000 & 0.74 & 0.75 & 0.11 & 0.72 & 0.73 & 0.03 \\
\hline \multicolumn{4}{|c|}{ Category } & & Low & & & Low & \\
\hline
\end{tabular}

Note. SMI: Score Maximum Ideal.

Based on Table 6, it is concluded that, in general, PBLCCS has been able to improve students' Mathematical Critical Thinking than EDI. However, the difference of N_Gain between Experimental and Control Class is still low.

\subsection{Result of Student's Test and Interview about Mathematical Critical Thinking Ability}

Qualitative analysis of students' works and interviews was conducted to identify their answers and the problems they have when completing the assigned tasks. The results of test show that most students still have obstacles when completing three questions: 1a, 2a, and 5a. To answer about question 2a, 3a dan 5a, all of which are indicators of Mathematical Critical Thinking (MCT). Meanwhile, students in general can answer questions 1a and $5 \mathrm{~b}$ as described below.

\section{Question 1a:}

If Today is Senin (Monday), can you exactly determine what day is the $41^{75}$ day? Write down what is known and your steps to resolve this question! 


(1) $\gg \rightarrow \operatorname{sen} i n$
$41^{75}$ hari lagi har apa
$\frac{(a m+b)^{n}=b^{n}(\bmod m)}{a \equiv b(1 \bmod m) \operatorname{maca} a c \equiv b c\left(\bmod u_{1}\right)}$
$41^{75}(\bmod 7)$
$\left(41^{2}\right)^{11}(\bmod 7)=41(\bmod 7)$

Figure 1. Answer of student 1

Answer for question 1a shows that, in general, students are able to use the theorem needed for the task, which is the congruency theorem with the characteristic of $(a m+b)^{n}=b^{n}(\bmod m)$ but they are still unable to use it to complete the task given. This means that the students cannot interpret the known information that 41 is close to 42 (multiple 7) which is the number of days in a week so that at the end the students cannot completely answer the assigned question.

To find out the problem that this student may have, the student was interviewed by the researcher, as follows:

Researcher: Your answer shows that you can find the right theorem, but why can't you use it properly?

Student 1: I remember the theorem but don't know how to use it. I am rather confused.

Researcher: Do you know that to determine the $41^{75}$ day, you need to use Modulo 7 ?

Student 1: Yes, I do.

Researcher: But why can't you complete the answer? I believe you know that 41 is close to 42 , and 42 is (multiple 7), right?

Student 1: I don't remember. I just can't complete it.

The interview shows that student 1 (female) has difficulty in determining that $41=42-1=6.7-1$. Although she has chosen the correct theorem, her final answer above is incorrect. Below is the answer of student 2 (male) who can complete his answer correctly (question 1a).

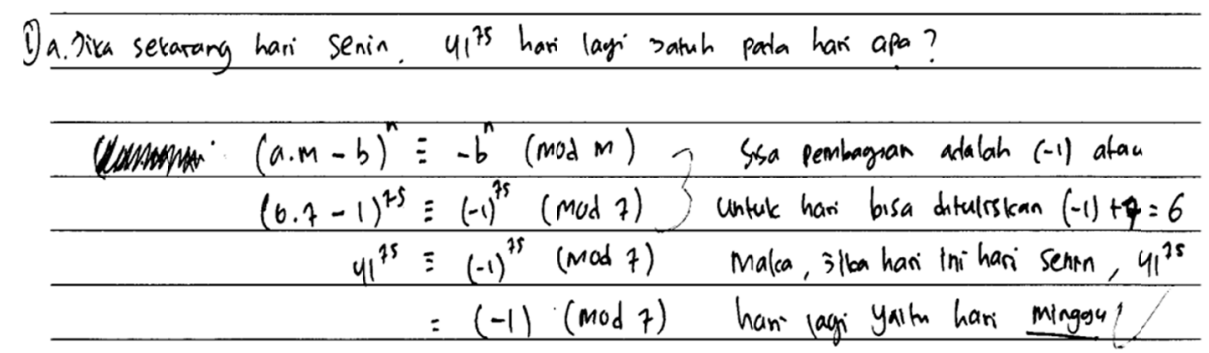

Figure 2. Answer of student 2

Figure 2 shows that student 2 was able to identify the correct theorem needed to answer the question and completed the answer. In the last step, he found $41^{75}=(-1)(\bmod 7)$, which means that $-1(\bmod 7)=$ $6(\bmod 7)$. So, she can conclude that the day $41^{75}$ is 6 days more or $(-1)$, or one day before Monday. As the conclusion, if today is Monday, the day $41^{75}$ is Sunday.

For question 2a below, the answer shows a student who can find the correct steps in answering the question but incorrect final result. Based on this figure, a male student 2 was able to identify the correct theorem needed to answer the question and completed the answer. In the last step, he found $41^{75}=(-1)(\bmod 7)$, which means that $-1(\bmod 7)=6(\bmod 7)$. So, she can conclude that the day $41^{75}$ is 6 days more or $(-1)$, or one day before Monday. As the conclusion, if today is Monday, the $41^{75}$ day is Sunday.

Question 2a: 
Given a series number $1.2+2.3+3.4+\cdots+n(n+1)$

How can you determine the amount of that series? Explain the amount of the series you have obtained and relate it to $2\left(\begin{array}{c}n+2 \\ 3\end{array}\right)$

The result of student's work can be seen below.

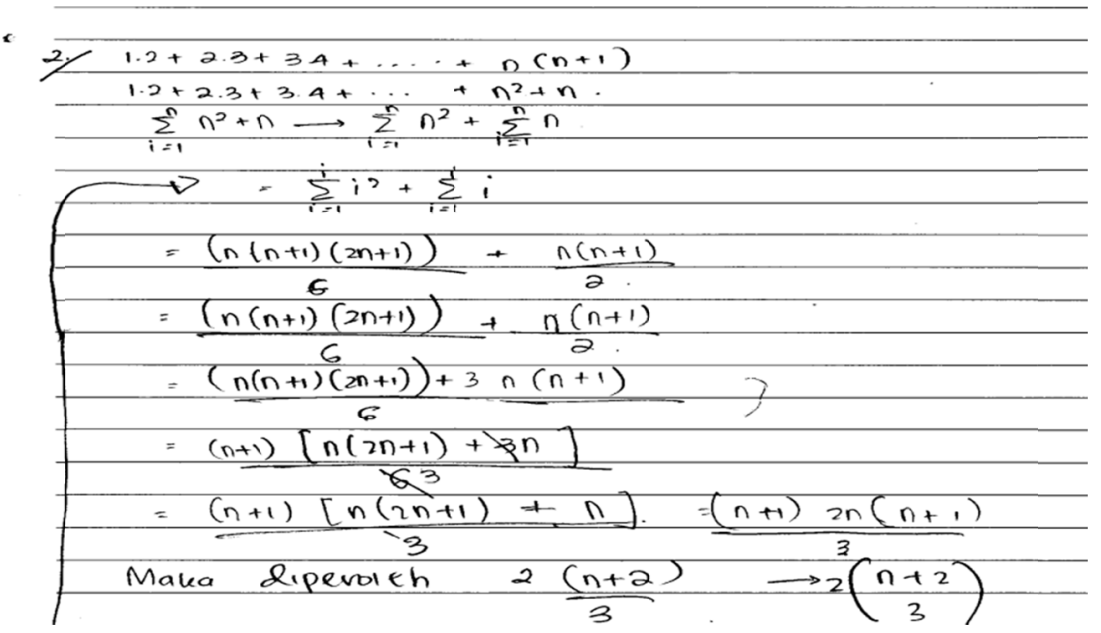

Figure 3. Answer of student 3

Although the answer of the student is still below expectation as she wrote $\sum_{i=1}^{n} n(n+1)=\sum_{i=1}^{n} n^{2}+n$ instead of $\sum_{i=1}^{n} i(i+1)=\sum_{i=1}^{n} i^{2}+i$, she had chosen the correct procedure. The process and concepts chosen were right but the final answer was still incorrect. It should be $\sum_{i=1}^{n} i^{2}+i=\sum_{i=1}^{n} i^{2}+\sum_{i=1}^{n} i=\frac{1}{6} n(n+$ 1) $(2 n+1)+\frac{1}{2} n(n+1)=\frac{1}{3} n(n+1)(n+2)$

The student has also made a mistake when relating $\frac{1}{3} n(n+1)(n+2)$ dengan $2\left(\begin{array}{c}n+2 \\ 3\end{array}\right)$.

To find out the reasons and challenges causing this mistake, the student was then interviewed. Below is the result of the interview.

Researcher: Do you have problem in completing this task?

Student 3: I don't really understand what the question means. When I read it again, I understand that I have to first identify the amount of the given series.

Researcher: Right. And why you write $\sum_{i=1}^{n} n(n+1)=\sum_{i=1}^{n} n^{2}+n$, you don't add up $n$ but $i$

Student 3: So, what is my mistake?

Researcher: You make mistake when writing the series amount in sigma. You have to write $\sum_{i=1}^{n} i(i+1)=$ $\sum_{i=1}^{n} i^{2}+i$, then after that, use the characters of sigma notation

Student 3: I don't know if that's wrong.

Researcher: Next, you also still make mistakes in determining the final answer and relates it to $2\left(\begin{array}{c}n+2 \\ 3\end{array}\right)$. What is the Problem?

Student 3: I don't know how to combine it.

Researcher: Alright, I hope you have a better comprehension now. 
Student 3: God willing.

The interview above shows that the student has not acquired the ability to explain the relevant sigma notation and relate its result with the given combination.

Question 5a has the lowest average score that students have obtained. Students' answer can be seen in picture 4 below.

\section{Question 5a:}

Student 3 (male) is going to buy a set (20 items) of school equipment consisting of books and pens with the total price of IDR 56 (in thousands). A book costs 3 (thousands) more expensive than the price of a pen, and the student should spend all the total money he has (the number of book should be more than that of pen).

Question: Explain in details the steps needed to complete the question above and recheck your answer carefully. The student's answer to the question above can be seen below.

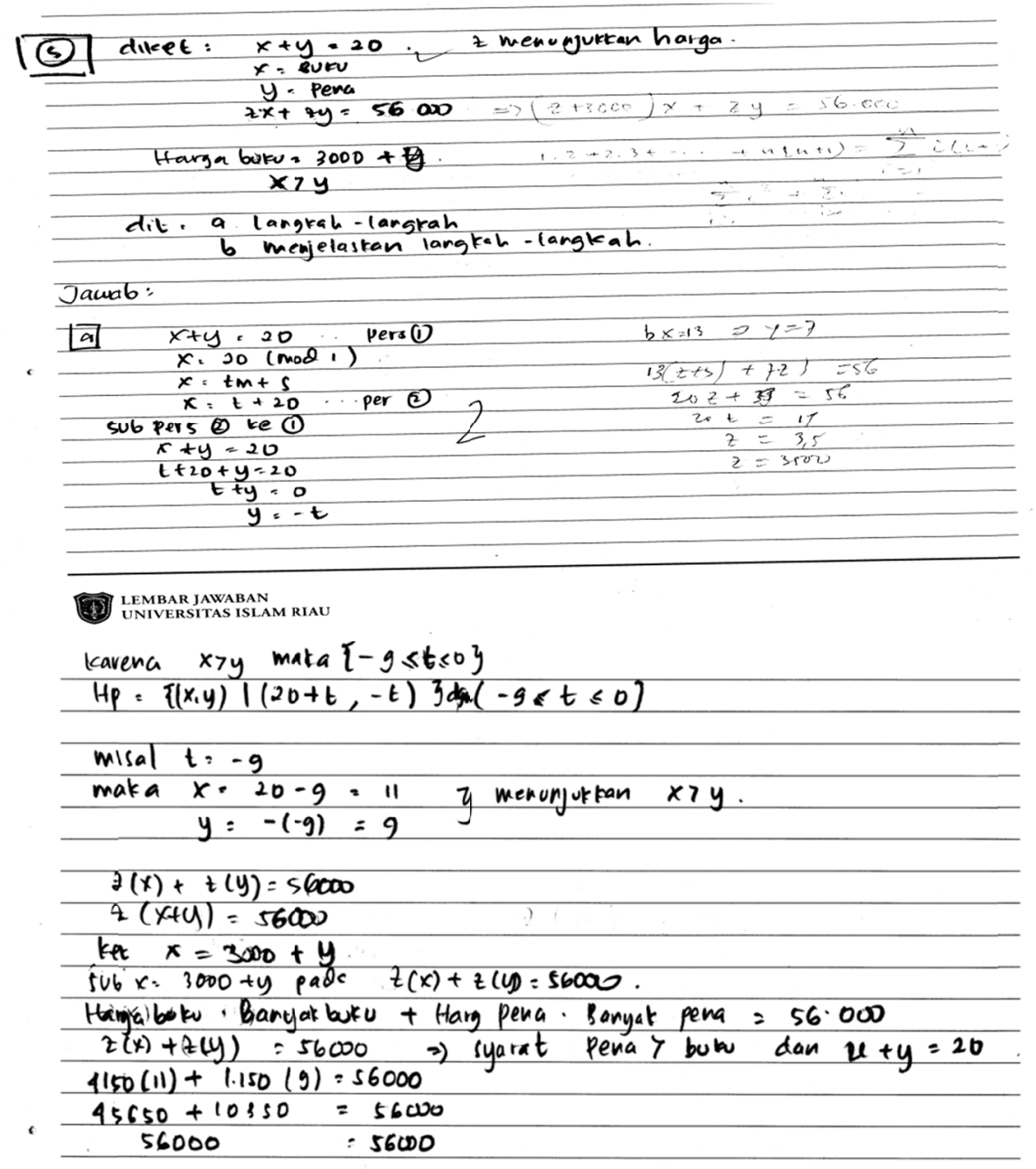

Figure 4. Answer of student 4

The result of the student's work above shows that he still experiences difficulties in transforming or interpreting mathematical problem into mathematical words. He should first define the price variable with variable $\mathrm{z}$ and determine whether it is the variable of book or pen price before adapting to the designated condition. The student made a mistake by making the equation of $\mathrm{x}=3000+\mathrm{y}$ for books and pens since the correct equation of both book and pen is $\mathrm{x}+\mathrm{y}=20$. The equation of book and pen prices is also incorrect and it should be $\mathrm{x}(\mathrm{z}+3000)+$ $y z=56000$ or simplified into $\mathrm{x}(\mathrm{z}+3)+\mathrm{yz}=56$ (in thousands). Although the student was able to relate one equation to another and use relevant concept required for the given problem, namely the concept of Linear Congruential (LC) and Linear Diophantine Equation (LDE), he was not able to show how he should get more 
books than pens. Moreover, the answer also shows that although the student was able to determine the amount of book and pen that he should purchase, how much each book and pen costs is left unanswered. Here is the result of interview between student and the researcher which results in the above finding.

Researcher: It seems that you still make mistakes in interpreting the problem given. Why?

Student: Yes, I am still confused in determining the price equation. I thought I was correct when using $z x+z y=56.000$ whereas $z$ is price. It's wrong, isn't it?

Reseracher: Yes, it's because first you have to determine which price? Book or pen?

Student: Really, I don't know that.

Reseracher: You also made mistake when choosing the equation $x=3000+y$. Do you know why?

Student: I thought I could make the equation of price, but I am wrong.

Researcher: Your price equation should be $x(z+3000)+y z=56000$ or $x(z+3)+z y=56$ (in thousands)

Student: You are right. Now, I understand.

Based on the interview, it is concluded that that student 3 still has problems in interpreting the given question. Although she can finish the question, he still makes mistakes in completing the overall answer to the given problem.

\section{Discussion}

Based on quantitative data analysis, it is concluded that there is an increased Mathematical Critical Thinking (MCT) skill of students in the experiment class who were taught by PBLCCS compared to those of control class taught by EDI. This finding is in line with some previous studies like that of Herman (2007) who found that Problem-Based Learning can improve the ability of high order mathematical thinking of junior secondary school learners. In addition, this finding is also supported by Jarnawi (2012) who has proven the effectiveness of cognitive conflict strategy in improving learners' high order mathematical thinking. Focusing on strategy, Ismaimuza (2010) also found that PBLCCS can improve the creative and critical thinking of junior secondary school. Finally, combining both cognitive conflict and cooperative learning, Zulkarnain (2013) concludes that this combination can improve students' mathematical understanding and communication compared to conventional class.

However, unlike the case of MCT skill, PBLCCS has unsatisfactory result on mathematical curiosity. The study found that there is no significant difference between the Mathematical Curiosity Attitude (MCA) of students in experimental class taught by PBLCCS and those in control class taught by EDI. This finding also corresponds with the results of previous studies of Kirschner et.al (2006), who found ineffectiveness in all constructivist learning methods such as PBL, inquiry and discovery learnings which provide excessive attention on learner's autonomy and neglect teacher's guidance and supervision. Over half a century of empirical research on this issue has given clear evidence that teaching methods which overestimate students' learning autonomy and minimize teacher's guidance were less effective and that it needs to be reviewed. Supporting this claim, Camp (1996) argues that without the awareness of the importance of teacher's guidance, PBL-based autonomy learning will not be that effective. In the Indonesian context, considering student's low curiosity, research results by Zetriuslita, et.al $(2014,2015)$ about the profile of students' mathematical critical thinking ability and Zetriuslita's (2015) student's mathematical curiosity have proven this concern. As such, teachers and other educators still need to make harder efforts, to find more creative ways to improve the mathematical curiosity of their students. They should identify ways by which learning autonomy is proportionally supported by teacher's guidance and instruction.

\section{Conclusion}

The discussion above leads to a conclusion. Although Problem-Based Learning and Cognitive Conflict Strategy (PBLCCS) can improve students' Mathematical Critical Thinking skill, it has not improved their Mathematical Curiosity Attitude. Therefore, to improve their mathematical curiosity in learning, students need to get accustomed to PBLCCS practices. The learning instruments (LKM) used should be more focused so that it can increase students' MCT skill.

\section{Acknowledgments}

Many people have been involved in writing this article. First, I would to deeply thank my dissertation supervisor who has provided insightful comments on this paper. Second, I would also like to express thank to my beloved 
students who have taken part as helpful participants in this study. Next, I would like to thank my institution which has given me a chance to pursue my doctoral study and supported my research. Finally, constructive and thoughtful suggestions and criticisms from readers are welcome.

\section{References}

Aktaş, G. S., \& Ünlü, M. (2013). Critical thinking skills of teacher's candidates of elementary mathematics. Procedia - Social and Behavioral Sciences, 93, 831-835. https://doi.org/10.1016/j.sbspro.2013.09.288

Binson, B. (2009). Curiosity Based Learning (CBL) program. US-China Education Review, 12(6), 13-22 https://doi.org/10.1109/ITHET.2012.6246005

Camp, G. (1996). Problem-Based Learning: A Paradigm Shift or a Passing Fad? Medical Education Online, 1(2), 1-6. https://doi.org/10.3402/meo.v1i.4282

Chukwuyenum, A. N. (2013). Impact of Critical thinking on Performance in Mathematics among Senior Secondary School Students in Lagos State. IOSR Journal of Research \& Method in Education, 3(5), 18-25.

Cohen, L., Manion, L, \& Morrison, K. (2007). Research methods in education (6th ed.). Companion Website.

Creswell, J. W. (2010). Research design: Qualitative, quantitative and mixed method approaches (3rd ed.). California (Translated by Achmad Fawaid).

Duron, R., Limbach, B., \& Waugh, W. (2006). Critical Thinking Framework for Any Discipline. International Journal of Teaching and Learning in Higher Education, 17, 160-166.

Fisher, A. (2001). Critical thinking. an introduction. Cambridge University Press.

Fisher, A. (2008). Berpikir kritis sebuah pengantar. Jakarta: Erlangga.

Herman, T. (2006). Pembelajaran Berbasis Masalah untuk Meningkatkan Kemampuan Berpikir Matematis Tingkat Tinggi Siswa Sekolah Menengah Pertama (SMP). Bandung: Program Pasca Sarjana UPI.

Hidayat, R. (2010). Pembelajaran Kontekstual dengan strategi REACT dalam Upaya Mengembangkan Kemampuan Pemecahan Masalah, Berpikir Kritis, dan Berpikir Kreatif matematis Mahasiswa Bidang Bisnis (Unpublished dissertation). Postgraduate school, Universitas Pendidikan Indonesia.

Innabi, H. (2003). Aspects of critical thinking in classroom instruction of secondary school mathematics teachers in Jordan. Retrieved from http://dipmat.math.unipa.it/pdf

Ismaimuza, D. (2010). Kemampuan Berpikir Kritis dan Kreatif Matematis Peserta didik SMP melalui Pembelajaran Berbasis Masalah dengan Strategi Konflik Kognitif (Unpublished dissertation). Postgraduate school, Universitas Pendidikan Indonesia.

Ismawati, Nugroho, S. E., \& Dwijayanti, P. (2014). Application of conceptual understanding procedures for improving student curiosity ang understanding concepts. Jurnal Pendidikan Fisika Indonesia, 10, 22-27. http://doi.org/10.15294/jpfi.v10i1.3047

Jarnawi. (2012). Implementasi Strategi Pembelajaran Konflik Kognitif Dalam Upaya Meningkatkan High Order Mathematical Thinking Peserta didik. Jurnal Pendidikan, 13(2), 65-76.

Kek, M. Y. C. A., \& Huijser, H. (2011). The power of problem-based learning in developing critical thinking skills: Preparing students for tomorrow's digital futures in today's classrooms. Higher Education Research \& Development, 30(3), 329-341. http://doi.org/10.1080/07294360.2010.501074

Kirschner, P. A., Sweller, J., \& Clark, R. E. (2006). Why minimal guidance during instruction does not work: An analysis of the failure of Constructivist, Discovery, Problem Based, Experiential, and Inquiry-Based Teaching. Educational Psychologist, 41(2), 75-86. https://doi.org/10.1207/s15326985ep4102_1

Kondakci, E. U., \& Aydin, Y. C. (2013). Predicting critical thinking skills of university students through metacognitive self-regulation skills and chemistry self-efficacy. Journal of Educational Science: Theory \& Practice, 13(1), 666-670.

MacSath, S., Wallace, J., \& Chi, X. (2009). Problem Based Learning in Mathematics. Toronto: The Literacy and Numeracy Secretariat.

McElmeel, S. L. (2002). Character education: A book guide for teachers, librarians, and parents. Greenwood Village, Colorado:Greenwood Publishing Group,Inc

Okinoğlu, O., \& Tandoğan, R. O. (2006). The Effects of Problem-Based Active Learning in Science Education on Students'Academic Achievement, Attitude, and Concept Learning. Turkey: Marmara University. 
Orey, M. (2010). Emerging Perspectives on Learning, Teaching, and Technology. Switzerland. Global Text Project.

Reio, T. G., \& Petrosko, J. M. (2006). The Measurement and Conceptualization of Curiosity. The Journal of Genetic Psychology, 167(2), 117-135. https://doi.org/10.3200/GNTP.167.2.117-135

Santrock, J. W. (2012). Life-Span Development (13th ed.). Translated by Benedictine Widyasinta. Perkembangan Masa Hidup. Erlangga dan Power Macro.

Siegel, H. (2010). Critical thinking. International Encyclopedia of Education, 6, 141-145. https://doi.org/10.1016/B978-0-08-044894-7.00582-0

Suhadak, M., \& Wutsqa, D. U. (2014). Pengembangan Perangkat Pembelajaran Sistem Persamaan Linear Dua Variabel Menggunakan Metode Inkuiri. PYTHAGORAS: Jurnal Pendidikan Matematika, 9(1), 60-69. Retrieved from http://journal.uny.ac.id/index.php/pythagoras

Surya. (2015). Strategi Kognitif dalam Proses Pembelajaran. Bandung: Alfabeta.

Thompson, C. (2011). Critical thinking across the curriculum: Process over Output. International Journal of Humanities and Social Science, 1(9), 1-7.

Woolfolk, A. E. (1984). Educational psychology for teachers. New Jersey: Prentice-Hall Inc.

Zetriuslita, Ariawan, R., \& Nufus, H. (2014). Profil kemampuan berpikir kritis mahasiswa dalam menyelesaikan masalah matematika berdasarkan tingkat kemampuan akademik. Laporan Hibah Fundamental Tahun Pertama. Lembaga Penelitian dan Pengabdian pada Masyarakat. Direktorat Jenderal Pendidikan Tinggi. Tidak dipublikasikan

Zetriuslita, Ariawan, R., \& Nufus, H. (2015). Profile ability think critically students in completing mathematical problems based on the level of academic ability. Proceeding The International Conference on Mathematics Science, Education, and Technology (ICOMSET). Faculty of Mathematics and Science, State University of Padang, Indonesia.

Zetriuslita. (2014). Profil sikap ilmiah rasa ingin tahu (curiosity) matematis mahasiswa. Jurnal Ilmu Pendidikan, $8(1), 41-46$.

Zulkarnain, I. (2013). Kemampuan pemahaman dan komunikasi matematis dalam pembelajaran kooperatif berbasis konflik kognitif (Unpublished dissertation). Post-graduate school, Universitas Pendidikan Indonesia.

\section{Copyrights}

Copyright for this article is retained by the author(s), with first publication rights granted to the journal.

This is an open-access article distributed under the terms and conditions of the Creative Commons Attribution license (http://creativecommons.org/licenses/by/4.0/). 